\title{
ПСИХОЛОГІЧНІ ОСНОВИ ПРОФІЛАКТИКИ ПРАКТИЧНИМ ПСИХОЛОГОМ КОНФЛІКТІВ У ПІДЛІТКОВОМУ СЕРЕДОВИЩІ
}

\begin{abstract}
Анотація. У статті надається теоретичний аналіз проблеми психологічних основ профілактичної діяльності практичним психологом конфліктних ситуацій у середовищі дітей підліткового віку. Звертається увага на психологічну характеристику конфлікту як соціально-психологічного явища та підліткового віку як важливого етапу розвитку особистості, аналізуються особливості конфліктів у підлітковому середовищі та психологічні аспекти їх профілактики у роботі практичного психолога. Обгрунтовуються методичні основи організації експериментального дослідження. У дослідженні проводиться психологічний аналіз та інтерпретація отриманих результатів.
\end{abstract}

Ключові слова: профілактика, підліток, підліткове середовище, конфлікт, прогнозування конфліктів, попередження конфліктів.

Yanovskaya Tamara

Poltava V.G. Korolenko National Pedagogical University

\section{PSYCHOLOGICAL FUNDAMENTALS OF PREVENTION OF CONFLICT PRACTICOLOGIST IN ADOLESCENT ENVIRONMENT}

Summary. The article provides a theoretical analysis of the problem of psychological foundations of preventive activities by a practical psychologist of conflict situations among adolescents. Attention is paid to the psychological characteristics of conflict as a socio-psychological phenomenon and adolescence as an important stage of personality development. Defining the essence of conflict as a socio-psychological phenomenon involves the disclosure of its characteristics such as the functions of conflict, its structure, typology, causes and dynamics. Conflict should be considered as a complex structural structure of the socio-psychological phenomenon, the main components of which are: conflicting parties, the subject of the conflict, the conditions of its course, as well as subjective components that reveal the features of conflict in the minds of participants: cognitive, emotional, motivational and strong-willed. The leading activity of a teenager is intimate and personal communication. The main content of adolescents' communication with others are issues of social problems, relationships between people, moral assessments of events and actions of others, personal relationships between adolescents and the problem of choosing values and self-affirmation as a person. Peculiarities of conflicts in the adolescent environment and psychological aspects of their prevention in the work of a practical psychologist are analyzed. It should be noted that the emergence of conflict situations among adolescents has objective prerequisites: conflict interaction is based on the collision of personal and group motives; the causes of conflict are directly related to the position of the adolescent in the environment, which is characterized by such concepts as position, status, role. The causes of such conflicts are always related to the violation of role expectations, the inadequacy of the internal setting of the status of a teenager, the violation of group norms. Forms of manifestation of such a conflict can be: the application of group sanctions, significant restriction or termination of informal communication between group members and the conflicting party; sharp criticism of him, euphoria from the conflicting party. The content of preventive work of a practical psychologist on conflicts in adolescence is the prediction of conflicts and their prevention. Conflict forecasting aims to identify the causes of conflict in potential development. Conflict prevention is the activity of a practical psychologist aimed at preventing conflict. The article also substantiates the methodological foundations of the organization of experimental research. The study provides psychological analysis and interpretation of the results. Keywords: prevention, adolescent, adolescent environment, conflict, conflict forecasting, conflict prevention.

$\Pi$ остановка проблеми. Різні етапи розвитку людського суспільства характеризуються пошуком способів едективного управління конфрліктами. В останні роки підвищився інтерес до до проблем вирішення кондрліктів між підлітками та їх оточенням. Підліткове середовище характеризується високою конфліктогенністю, а переважна більшість учнів та дорослих при цому не мають достатніх знань, умінь, навичок, що сприяють попередженню та конструктивному розв'язанню конфрліктів. Це обумовлює загрозу зниження ефективності взаємодії підлітків з однолітками й дорослими.

3 розвитком психологічної служби в Україні розширюються можливості профрілактики конфліктних ситуацій у підлітковому середовиші саме за участю практичних психологів. Тому актуальним $є$ визначення теоретичних й практичних засад такого напряму діяльності практичних психологів для за- вчасного прогнозування потенщійних конорліктних ситуащій та професійного управління ними.

Аналіз останніх досліджень та публікацій. Аналіз психолого-педагогічної літератури свідчить: генезис підходів до розробки проблеми конфліктів вивчали А. Анцупов, Л. Козер, О. Маруховська, В. Орлянський [5, с. 54; 7, с. 93]. Соціально-психологічні аспекти конфрлікту досліджували О. Бондарчук, Н. Грішина, Л. Мороз, О. Сафрін, А. Шипілов [2, с. 122-125; 9, с. 192]. М. Дойч, один iз зарубіжних теоретиків конфрлікту, описуе два його різновиди: деструктивний i продуктивний. Деструктивний конфлікт призводить до порушень у взаємодії, а продуктивний конфрлікт частіше породжується відмінностями у точках зору на певну проблему чи способи її вирішення [6, с. 104].

Питанням виділення видів конфоіктів займалися А. Анщупов, Н. Грішина, М. Дойч, С. Смельянов, 
I. Пономарьов, де підставами для класифікащії виступали ріноманітні ознаки, зокрема, вид, тип, обсяг, тривалість конфлікту, ступінь впливу, витоки, зміст, значущість, тип вирішення, форма прояву, соціально-психологічний ефект, спрямованість, мотиви учасників, наслідки, час протікання, джерела впливу [1, с. 98-145]. Гендерні та вікові відмінності людей як причини виникнення конфрліктів вивчалися Л. Орбан-Лембрик [6, с. 155-161]. Положення про необхідність конструктивного розв'язання конорліктів та питання їх профрілактики у підлітковому й освітньому середовищі розглядаються у працях Л. Карамушки, Н. Пов’якель, В. Семиченко, Н. Тализіної [4, с. 145-198; 10, с. 125-136].

Виділення не вирішених раніше частин загальної проблеми. Отже, потрібно зазначити, що підлітковий вік є кризовим періодом у житті дитини, якому характерні агресивність, конфліктність, виникнення почуття дорослості, розвиток самосвідомості, ідентичності та статевої ідентичності як основної її характеристики, зміна самооцінки та рівня домагань підлітка. Зарубіжними й вітчизняними вченими на достатньому рівні вивчені та обгрунтовані причини конолтіктів, особливості їх проявів у підлітковому середовищі (між дітьми підліткового віку та однолітками чи дорослими).

Проте аналіз однієї з актуальних проблем особливостей прояву конфрліктів у середовищі дітей підліткового віку показав, що на сучасному етапі профілактична діяльність практичних психологів стосовно прогнозування й попередження даного явища недостатньо ефективною. Тому психологам потрібно спрямовувати зусилля на вдосконалення системи заходів, спрямованих на охорону психологічного здоров'я; попередження неблагополуччя у розвитку учнів; створення психологічних умов, сприятливих для цього розвитку.

Мета статті. Основна мета полягає у аналізі психологічних засад профілактики практичним психологом конфрліктів у підлітковому середовищі. Завдання полягають у теоретичному аналізі проблеми профілактики конфрліктів у підлітковому середовищі у роботі практичного психолога; визначенні методичних засад експериментального дослідження психологічних основ профілактики практичним психологом конфрліктів у підлітковому середовищі; експериментально виявити психологічні особливості конфрліктів у середовищі підлітків; розроблення рекомендацій для практичних психологів щодо профілактики коноліктів серед дітей підліткового віку.

Виклад основного матеріалу дослідження. Для того, щоб практичний психолог був у змозі ефрективно проводити профрілактичну діяльність у підлітковому середовищі стосовно конфрліктів, йому спочатку потрібно знати, з якими видами конфліктів та особливостями їх проявів він може зустрітися і що робити у подальшому для їх прогнозування і попередження.

Для визначення особливостей конфліктної поведінки підлітків проведено методику на оцінку рівня конфрліктності особистості (за Н. Кіршевою, Н. Рябчіковою) [3, с. 56-64]. Проаналізуємо отримані результати. Середній бал рівня конфоліктності підлітків становить 28,9, що відповідає середньому рівню. Це означає, що більшості підліткам притаманна схильність активно вступати у конфліктну взаємодію, самостійно ініціювати та створювати конорліктні ситуащіі, що розвинена на середньому рівні. Якісний аналіз отриманих результатів дозволяе виділити групи досліджуваних із загального контингенту. Як свідчать дані, дуже високий і високий рівень розвитку конфрліктності виявлений у 20,5\% підлітків. Рівень вище та трохи вище середнього діагностовано у 12,9\% дітей. Середній рівень конфрліктності проявляють 33,3\% опитуваних. 25,6\% досліджуваним притаманним $є$ рівень конфрліктності нижче або трохи нижче середнього. I низький або дуже низький рівень конфрліктності діагностовано у 7,7\% підлітків.

Отже, як свідчать отримані результати, підлітки переважно мають середній рівень розвитку конфрліктності. В той же час заслуговуе на увагу той фракт, що у чверті досліджуваних високий рівень розвитку конфрліктності, тобто вони не лише активно вступають у різні конфрліктні ситуащій, а й самостійно їх ініціюють та створюють. Ці дані узгоджуються 3 віковими особливостями розвитку особистості та міжособистісних стосунків підлітків, для яких підвищення конфрліктів є закономірним явищем.

Проаналізуемо статеві відмінності у рівні розвитку конфрліктності дітей підліткового віку. 3 отриманих результатів видно, що суттевих відмінностей у рівні конфліктності підлітків різної статі не виявлено. Загалом він є середнім або близьким до середнього (хлопщі - 35,7\%, дівчата $32 \%$ ). Відмінності є лише в тому, що дуже низький рівень розвитку конфліктності виявлено лише у дівчат (4\%), а дуже високий - у хлопців (14,3\%).

Перейдемо до розгляду домінуючих стратегій поведінки підлітків у конфлікті. Як видно з отриманих результатів, 28,2\% досліджуваних у конфрліктній ситуащії виражають стиль суперництва, що характеризуеться активністю, прагненням розв'язати конфрлікт власним способом, відсутністю зацікавленості у співпраці з іншими учасниками конфолікту, прагненням задовольнити лише власні інтереси, нав'язати своє рішення. Для 25,6\% підлітків типовою є стратегія компромісу, яка характеризується взаємними поступками, усвідомленням неможливості задоволення інтересів обох сторін, згодою на часткове або тимчасове вирішення конфлікту. Для 23,1\% дітей провідною є стратегія уникнення, тобто їм притаманна відсутність прагнення до співпраці з іншими, відсутність тенденції як до відстоювання власних інтересів, так й до жертвування ними, прагнення до відкладання проблеми чи перекладання відповідальності за неї на інших.

Менш вираженою у підлітковому середовищі є стратегія поступливості, притаманна 15,4\% підліткам, що виявляеться у відсутності дій учнів, спрямованих на збереження та відновлення сприятливих відносин з опонентом завдяки згладжуванню стосунків за рахунок власних інтересів.

Найменш вираженою у підлітковому середовищі є стратегія співпращі, яка притаманна 7,7\% досліджуваних, тобто у конфлгіктній ситуащії підлітки в недостатній мірі прагнуть до співпраці, врахування як власних інтересів, так й інтересів протилежної сторони, не характеризуються вмінням знайти альтернативне рішення, увагою до побажань, цілей, установок інших учасників конфлікту.

Проаналізуемо статеві відмінності у виборі стратегії поведінки підлітків у конфрлікті. Результати свідчать, що загалом для хлопців і дівчат притаманним $є$ домінування стратегій суперни- 
цтва (відповідно 35,7\% і 24\%) і компромісу (35,7\% і $20 \%$ ), хоча у хлопців вони виражені яскравіше. Дівчата, на противагу хлопцям, більш схильні до прояву співробітництва (відповідно 12\% і 0\%) і уникнення (28\% і 14,3\%), тобто вони прагнуть до співпраці, врахування власних інтересів та протилежної сторони, або ж, навпаки, виявляють прагнення до відкладання проблеми.

Узагальнимо отримані результати щодо особливостей конфрліктної поведінки підлітків. 3 метою виявлення зв'язку між рівнем конфрліктності підлітків та стилем їх реагування у конфлікті об'єднаємо учнів у три групи: 3 високим рівнем конфрліктності (дуже високим, високим, вище середнього рівня за методикою на оцінку рівня конфрліктності особистості); з середнім рівнем кондрліктності (трохи вищим за середній, середнім, трохи вищим за середній рівень за методикою на оцінку рівня конфрліктності особистості); 3 низьким рівнем конфрліктності (нижчим за середній, низьким, дуже низьким рівнем конфліктності за методикою на оцінку рівня конфрліктності особистості). Проаналізуемо отримані дані і виділимо групи підлітків з різними проявами конфрліктності.

Загалом для підлітків найбільш характерним є середній рівень конфрліктності, більш типовими стратегіями реагування у конфлікті для них є суперництво і компроміс, найменш розповсюдженою - стратегія співробітництва. Підлітки з низьким рівнем кондрліктності обирають такі стратегї реагування у конфрлікті як уникнення та поступливість, тобто вони або взагалі намагаються уникати вирішення конфліктних ситуацій, що склалися, або ж прагнуть вийти з конфлікту шляхом ігнорування власних інтересів та поступок іншій стороні.

Підлітки 3 середнім рівнем конфрліктності демонструють різні способи поведінки у конфрліктних ситуаціях від уникнення до суперництва, від співробітництва до пристосування. Але найбільш типовим для них є стиль компромісу, тобто намагання частково задовольнити як свої інтереси, так й інтереси іншого.

Для підлітків з високим рівнем конфліктності притаманним є стиль суперництва у конфлікті, тобто вони здійснюють активні дії для задоволення власних потреб і досягненні перемоги у ситуащії, що склалася.

Отже, коли практичний психолог розуміє особливості розвитку особистості підлітка, знає, що дитині підліткового віку притаманна підвищена конфрліктність та агресивна реакція певного виду на будь-який зовнішній подразник, він може застосовувати психолого-педагогічні шляхи подолання конфліктів у підлітковому середовищі за допомогою профрілактичної діяльності [8, с. 164-189].

Профрілактика починається тоді, коли ще немає особливих складнощів у поведінщі дитини. Разом із тим психологи на основі проведення моніторингу особливостей та умов індивідуального розвитку особистості, сощіально-психологічних змін у житті суспільства прогнозують можливість появи тих чи інших ускладнень і проводять попереджувальну роботу. Профрілактична робота є тим аспектом діяльності психологів, який спрямований не стільки на розв'язання сьогоденних проблем, скільки на перспективу. Профрілактична робота з управління конфрліктів у підлітковому середовищі є таким складним процесом, що включає в себе: прогнозування конфліктів та оцінку їх фрункціональної спрямованості; попередження або стимулювання конфрікту; регулювання конфрлікту; вирішення кондрлікту. Зміст профрілактичної роботи практичного психолога щодо конфоліктів у середовищі підлітків складає прогнозування конфліктів та їх попередження.

У сучасні психолого-педагогічній практищі значного поширення набуло проведення спеціальних групових занять для підлітків, 3 метою навчання ïx ефрективним прийомам міжособистісного спілкування, самостійного попередження та вирішення конфрліктів у різних сдрерах спілкування. В основу таких занять покладено принщипи проведення соціально-психологічного тренінгу. Саме така форорма профрілактичної роботи мае ряд переваг: дозволяе охопити велику кількість підлітків, дозволяе досягти позитивних змін не лише у становленні міжособистісних взаємин, а й у особистісному розвитку підлітків, а також є умовою попередження конфрліктів.

У випадку проведеного дослідження для профрілактики кондрліктів у середовищі дітей підліткового віку пропонуеться використовувати спеціальну програму, що базуеться на концепції навчання, побудованій на взаємодії та обміні досвідом. Заняття проводиться як тренінг один раз на тиждень й розраховані на 1,5 години, складаються 3 розминки (10 хвилин), вправ та їх обговорень (70 хвилин), висновків (10 хвилин). Максимальна у групі кількість учасників до 20 людей. Якщо ї більше, то створюються окремі групи, які наприкінці роботи об’еднуються для обговорення результатів.

Метою даної програми є популяризація тренінгу як фрорми навчання та методів розв'язання конфліктів; розвиток навичок довірливого спілкування в учасників тренінгу; активізація творчого пошуку та досвіду учасників тренінгу; створення доброзичливої, довірливої атмосфери у групі. Для проведення занять в приміщенні стільці ставляться колом або підковою. Після кожного заняття пропонується домашне завдання: повторення пройденого матеріалу або підготовка історій для наступних занять. На першому занятті група приймає та затверджує правила своєї роботи. У складі програми 7 занять, що мають назви: ставлення до конфлікту, конфліктний ескалатор, роль установок у розвитку конорліктів, поведінка в ситуації конфлікту, уміння слухати, уміння спілкуватися, позитивна сила. В ході занять підлітки мають змогу ознайомитися з природою конфрлікту та проаналізувати його позитивну й негативну роль, визначити шляхи його врегулювання; обговорити реальні та змодельовані ситуації конфлікту й знаходити способи встановлення та врегулювання міжособистісних стосунків; пізнати поняття «ярлик» та визначити його роль у вирішенні конорліктної ситуації; ознайомитися й проаналізувати схему позицій партнерів у спілкуванні і визначити провідну стратегію поведінки у конфрлікті, продемонструвати конфрлікту ситуацію, в якій показуеться певний вид поведінки, обговорити, як використаний вид поведінки у конфрлікті впливає на їх емоційний стан та почуття.

Висновки і пропозиції. Аналіз проблеми свідчить, що конфлікт є складним за своєю структурною будовою соціально-психологічним явищем, основними складовими якого є: кондрліктуючі сторони, предмет конфлікту, умови його перебігу, а також суб'єктивні складові, що розкривають особливості 
відображення конорікту в свідомості учасників: пізнавальні, емоційні, мотиваційні й вольові. Основними стадіями процесу конфрлікту є: виникнення обєктивної конорліктної ситуації; іiі усвідомлення, що завжди емоційно забарвлене; здійснення конфрліктної поведінки; розв'язання кондрлікту. Конфрлікти бувають дуже різноманітними i ïx можна класифікувати за різними ознаками.

Виникнення конфрліктів у підлітковому середовищі має об'єктивні передумови, викликані особливостями вікового розвитку. У міжособистісних взаєминах підлітків мають місце три основні види конфліктів: у колі родини; у навчальній діяльності, $з$ педагогами; у спілкуванні, з однолітками. Підлітковий вік характеризуеться підвищеною збудливістю дітей, притаманними їм кондрліктністю й агресивністю.

У ході визначення особливостей конфліктів у підлітковому середовищі отримані результати свідчать, що для учнів найбільш характерним $€$ середній рівень конфрліктності, більш типовими стратегіями реагування у конфлікті для них $є$ суперництво й компроміс, найменш розповсюдженою - стратегія співробітнищтва. Підлітки 3 низьким рівнем конфліктності обирають такі стратегіі реагування у конфрлікті як уникнення та поступливість, тобто вони або намагаються уникати вирішення конфліктних ситуацій, або ж прагнуть вийти 3 конфрлікту шляхом ігнорування власних інтересів та поступок іншій стороні. Підлітки з середнім рівнем конфліктності демонструють різні способи поведінки у конфліктних ситуаціях від уникнення до суперництва, від співробітництва до пристосування. Але найбільш типовим для них є стиль компромісу, тобто намагання частково задовольнити як свої інтереси, так й інтереси інших. Для підлітків 3 ви- соким рівнем конфрліктності притаманним у конфрліктів є стиль суперництва, тобто вони здійснюють активні дії для задоволення власних потреб і досягнення перемоги у ситуації, що склалася.

Так як виникнення конфрліктів у підлітковому віці є закономірним явищем і призупинити його просто неможливо, то практичний психолог, знаючи можливі особливості їх виникнення та різноманітні реакції дітей на зовнішні подразники, може спробувати спрогнозувати й попередити можливі конфрлікті ситуащії у середовищі підлітків. Цілеспрямована профрілактична діяльність психологів, що є системою заходів, спрямованих на створення психологічних умов, сприятливих для розвитку підлітків, дозволяе значно знизити їх потенційну конфрліктність. У сучасній психологічній практищі значного поширення набуло проведення спеціальних групових занять для підлітків, 3 метою навчання їх едективним прийомам міжособистісного спілкування, самостійного попередження та вирішення конфліктів у різних сорерах спілкування. В основу таких занять покладено принщипи проведення соціально-психологічного тренінгу. Саме така форма проведення профрілактичної роботи має ряд переваг: дозволяе охопити велику кількість підлітків; дозволяе досягти позитивних змін у становленні міжособистісних взаємин та особистісному розвитку підлітків, що також є умовою попередження конфоліктів. Програма профрілактики конфліктів серед підлітків розроблена з урахуванням їх психологічних особливостей, орієнтована на навчання підлітків взаєморозумінню та співробітництву, є достатньо зручною для їі проведення психологом як у рамках навчально-виховного процесу закладу середньої освіти, так і на базі позашкільних установ, що працюють з підлітками.

\section{Список літератури:}

1. Гуменюк Л. Й. Соціальна конфліктологія : підручник. Львів : Львівський державний університет внутрішніх справ, 2015. 563 с.

2. Долинська Л. В. Психологія конфлікту : Навчальний посібник. Київ : Каравела, 2017. 304 с.

3. Жаворонкова Г. В. Управління конфрліктами : Навчальний посібник. Київ : Кондор, 2010. 172 с.

4. Ложкін Г. В. Психологія конфлікту : теорія і сучасна практика : Навчальний посібник. Київ : ВД «Професіонал», 2007. $416 \mathrm{c}$.

5. Матвійчук Т. Ф. Конфрліктологія : навчально-методичний посібник. Львів : Вид-во «ГАЛИЧ-ПРЕС», 2018.76 с.

6. Орбан-Лембрик Л. Е. Психологія управління : посібник. Київ : Академвидав, 2003. 255 с.

7. Орлянський В. С. Конфліктологія : Навчальний посібник. Київ : Центр учбової література, 2007. 160 с.

8. Русинка I. I. Конфліктологія. Психотехнології запобігання і управління конфліктами : Навчальний посібник. Київ : ВД «Професіонал», 2007. 332 с.

9. Свидрук I. І. Психологія управління та конфліктологія : підручник. Львів : Видавництво Львівського торговельно-економічного університету, 2017. 320 с.

10. Карамушка Л. М. Технології роботи організаційних психологів : Навчальний посібник. Київ : Фірма «ІНКОС», 2005. $366 \mathrm{c}$.

\section{References:}

1. Gumeniuk L. Y. (2015) Sotsialna konflictologiia [Social conflictology]. Lviv: Lvivskii derzhavnii universitet vnutrishnikh sprav.

2. Dolinska L. V. (2017) Psikhologiia konflictu [Psychology of conflict]. Kyiv: Karavela.

3. Zhavoronkova G. V. (2010) Upravlinnia konflictami [Conflict management]. Kyiv: Kondor.

4. Lozhkin G. V. (2007) Psikhologiia konflictu: teoriia i suchasna praktika [Psychology of conflict: theory and modern practice]. Kyiv: VD Professional.

5. Matviichuk T. F. (2018) Konflictologiia [Conflictology]. Lviv: GALICH-PRES.

6. Orban-Lembrik L. E. (2003) Psikhologiia upravlinnia [Management psychology]. Kyiv: Akademvidav.

7. Orlianskii V. S. (2007) Konflictologiia [Conflictology]. Kyiv: Tsentr uchbovoi literature.

8. Rusinka I. I. (2007) Konflictologiia. Psikhotekhnologii zapobigannia i upravlinnia konflictami [Conflictology. Psychotechnology of conflict prevention and management]. Kyiv: VD VD Professional.

9. Svidruk I. I. (2017) Psikhologiia upravlinnia ta konflictologiia [Management psychology and conflictology]. Lviv: Vidavnitstvo Lvivskogo torgovelno-ekonomichnogo universitetu.

10. Karamushka L. M. (2005) Tekhologii roboti organizatsiinikh psikhologiv [Technologies of work of organizational psychologists]. Kyiv: Firma INKOS. 